\title{
A novel mutation in calcium-sensing receptor gene associated to hypercalcemia and hypercalciuria
}

Eugenio Mastromatteo ${ }^{1}$, Olga Lamacchia ${ }^{1}$, Michela Rosaria Campo ${ }^{1}$, Antonella Conserva ${ }^{1}$, Filomena Baorda ${ }^{2}$, Luigia Cinque ${ }^{2}$, Vito Guarnieri ${ }^{2}$, Alfredo Scillitani ${ }^{3}$ and Mauro Cignarelli ${ }^{\text {** }}$

\begin{abstract}
Background: Familial Hyperparathyroidism (HPT) and Familial benign Hypocalciuric Hypercalcemia (FHH) are the most common causes of hereditary hypercalcemia. FHH has been demonstrated to be caused by inactivating mutations of calcium-sensing receptor (CaSR) gene, involved in PTH regulation as well as in renal calcium excretion.

Case presentation: In two individuals, father and son, we found a novel heterozygous mutation in CaSR gene. The hypercalcemia was present only in father, which, by contrast to the classic form of $\mathrm{FHH}$ showed hypercalciuria (from 300 to $600 \mathrm{mg} / 24 \mathrm{~h}$ in different evaluations) and a Calcium/Creatinine ratio of 0.031, instead of low or normal calciuria $(<0.01$ typical finding in $\mathrm{FHH})$. His son showed the same mutation in CaSR gene, but no clinical signs or hypercalcemia although serum ionized calcium levels were close to the upper limit of normal values $(1.30 \mathrm{mmol} / \mathrm{L}$ : normal range: 1.12-1.31 mmol/L). Sequence analysis revealed a point mutation at codon 972 of CaSR gene (chromosome 3q), located within cytoplasmic domain of the CaSR, that changes Threonine with Methionine. The father was treated with Cinacalcet $90 \mathrm{mg} / \mathrm{day}$, with a decrease of total serum calcemia from an average value of $12.2 \mathrm{mg} / \mathrm{dl}$ to $10.9 \mathrm{mg} / \mathrm{dl}$.

Conclusion: This is a case of a novel inactivating point mutation of CaSR gene that determines an atypical clinical presentation of $\mathrm{FHH}$, characterized by hypercalcemia, hypercalciuria and inadequate normal PTH levels. Functional assay demonstrated that the $972 \mathrm{M}$ variant influenced the maturation of the protein, in terms of the post-translational glycosylation. The impairment of the receptor activity is in keeping with the specific localization of the 972 residue in the C-terminal tail, assigned to the intracellular signalling, that on the basis of the our findings appears to be differently modulated in parathyroid gland and in kidney.
\end{abstract}

Keywords: CaSR gene, Hyperparathyroidism, FHH, Hypercalcemia, Hypercalciuria, Hypocalciuria

\section{Background}

CaSR gene (chr. 3q13.3-21) encodes for a protein of 1078 aminoacids present in the plasma membrane as a dimer. CaSR is a member of the G-protein coupled receptors and its structure has 3 different domains [1,2]. The extracellular domain (612 aminoacids) binds extracellular calcium through its multiple negative charges allowing the CaSR to function as a sensitive detector of extracellular calcium; the transmembrane part (250

\footnotetext{
*Correspondence: mauro.cignarelli@unifg.it

'Unit of Endocrinology and Metabolic Diseases, Department of Medical and Surgical Sciences, University of Foggia, Italy, Viale Pinto, 1, 71122 Foggia, Italy Full list of author information is available at the end of the article
}

aminoacids) has 7 membrane-spanning domains; the intracellular tail (216 aminoacids) interacts with the Gproteins and filamin A to translate within the cells the signal produced by the extracellular calcium binding $[3,4]$. Through these and other pathways, CaSR may influence cell function, especially $\mathrm{PTH}$ secretion from parathyroid cells, but also cell proliferation and gene expression $[5,6]$. This process takes place mainly in parathyroid and kidney tubular cells, regulating calcium concentrations in extracellular fluid. In the kidney, the CaSR performs different tasks depending on the various tubular segments in which it is located [7]. It is expressed on the luminal membrane of the proximal 
tubular cells where it senses the increase in calcium luminal concentrations and inhibits cAMP production induced by PTH $[8,9]$. CaSR is expressed on the basolateral membrane of the thick ascending limb of Henle loop [9], where modulates the electric gradient generated by sodium-potassium reabsorption and potassium recycling, inhibiting the sodium-potassium-chloride carrier activity. Therefore, after an increase in serum calcium, CaSR decreases the potential, eventually supporting calcium reabsorption and promoting calcium excretion [5]. In the distal convoluted tubule, CaSR is located on the basolateral membrane of tubular cells where reduces the active calcium reabsorption by interfering with the calcium pump function through a phospholipase $C$ dependent mechanism [10]. In adults, inactivating mutations of CaSR gene are found in $\mathrm{FHH}$, an autosomal dominant disease characterized by moderate but significant hypercalcemia, accompanied by few symptoms [11,12], with inappropriately normal serum PTH levels, and by a low or normal urinary calcium levels [12-14] with histologically normal parathyroid glands. The condition does not require treatment, and responds poorly to parathyroidectomy. FHH should be distinguished from primary $\mathrm{HPT}$, in which the elevated serum and urinary calcium levels are normalized by successful parathyroid surgery. Familial primary HPT is inherited as autosomal dominant mutation either as the single lesion (isolated HPT form) [15] or in the context of multiple endocrine neoplasia (MEN) type 1 or 2A [16] and the HPT-jaw tumor syndrome [17].

\section{Case presentation}

A 68-year-old male patient presented with slight fatigue and intermittent polyuria. His family history was positive for osteoporosis, negative for fractures and nefrolitiasis. In childhood he was subjected to a jaw cementoma asportation. He underwent several surgical procedures because of recurrent nefrolitiasis since 25 years. He has also been on hypertension treatment since 30 years. At presentation we observed arterial pressure of $120 / 70 \mathrm{mmHg}$ and pulse rate of 70 beats/min with his habitual antihypertensive therapy (Losartan $50 \mathrm{mg} /$ day). Physical examination was unremarkable: weight $75 \mathrm{Kg}$, height $173 \mathrm{~cm}$, body mass index $25.1 \mathrm{Kg} / \mathrm{m}^{2}$. Total serum calcium level at first evaluation was $11.6 \mathrm{mg} / \mathrm{dl}$, with a PTH improperly normal $(25.7 \mathrm{pg} / \mathrm{ml})$. Low values of serum 25-hydroxyVitamin $\mathrm{D}_{3}$ was also observed $(16 \mathrm{ng} / \mathrm{ml})$. During the following visits we found hypercalciuria (from 300 to $600 \mathrm{mg} / 24 \mathrm{~h}$ in different evaluations) and a $\mathrm{Ca} / \mathrm{Cr}$ ratio of 0.031. Glycemia, TSH, prolactin, IGF-1, urine metanephrines levels were in normal range. We found higher values of serum Anti-Parietal-Cells-Antibodies (APCA), suggestive for chronic autoimmune gastritis. Laboratory results are shown in Table 1.

Neck echography, NMR and 99mTc-sesta MIBI tomoscintigraphy were negative for parathyroids glands images. Abdomen echography and CT showed bilateral polycystic kidney (maximum diameter $8.5 \mathrm{~cm}$ ). Bone density scan (DXA) showed normal bone mineral density (Femur Tscore 1.07, Lumbar T score 1.3). Recent orthopantomography was negative for jaw lesions.

The patient was treated for 7 months with Cinacalcet $90 \mathrm{mg} /$ day, since at that time we ignored the existence of the CaSR mutation. However, although Cinacalcet is not indicated for $\mathrm{FHH}$ treatment, we obtained a slight decrease of calcemia, but the therapy was stopped because of side effects appearance (hypotension, nausea). Subsequently, he refused other specific therapies. During a 4 years follow-up period hypercalcemia, hypercalciuria and normal levels of PTH persisted. A heterozygous mutation in exon 7 of the CaSR gene was found, predicting a p.T972M amino acid substitution in cytoplasmic tail of CaSR (Figure 1). The same mutation we found in one of his three screened sons, a 41-year-old men (Figure 2), who is currently asymptomatic and shows serum ionized calcium level of $1.30 \mathrm{mmol} /$ $\mathrm{L}$, close to the upper normal limit (n.v. 1.12-1.31), normal calciuria $(195 \mathrm{mg} / 24 \mathrm{~h})$ and PTH, but also a 25 hydroxyVitamin $\mathrm{D}_{3}$ deficiency $(12.3 \mathrm{ng} / \mathrm{ml}$ ) (Table 2$)$.

Table 1 Laboratory results (follow up period)

\begin{tabular}{lcccc}
\hline & \multicolumn{3}{c}{} & Patient l:1 \\
\cline { 2 - 5 } & First values & $\begin{array}{c}\text { 1 year follow-up } \\
\text { (after cinacalcet) }\end{array}$ & $\begin{array}{c}\text { 2 years follow-up } \\
\text { (no specific therapy) }\end{array}$ & $\begin{array}{c}\text { 4 years follow-up } \\
\text { (no specific therapy) }\end{array}$ \\
\hline s-Ca total (correct) (n.v. 8.8-10.6) & $11.6 \mathrm{mg} / \mathrm{dl}$ & $10.9 \mathrm{mg} / \mathrm{dl}$ & $12.96 \mathrm{mg} / \mathrm{dl}$ & $11.8 \mathrm{mg} / \mathrm{dl}$ \\
s-PO4 (n.v. 2.7-4.5) & $3 \mathrm{mg} / \mathrm{dl}$ & $2.5 \mathrm{mg} / \mathrm{dl}$ & $2.2 \mathrm{mg} / \mathrm{dl}$ & $2.4 \mathrm{mg} / \mathrm{dl}$ \\
s-Creatinine (n.v. 0.2-1.2) & $1.08 \mathrm{mg} / \mathrm{dl}$ & $1.12 \mathrm{mg} / \mathrm{dl}$ & $1.31 \mathrm{mg} / \mathrm{dl}$ & $1.19 \mathrm{mg} / \mathrm{dl}$ \\
s-PTH (n.v. 5-40) & $25.7 \mathrm{pg} / \mathrm{ml}$ & $33 \mathrm{mg} / \mathrm{dl}$ & $19.4 \mathrm{mg} / \mathrm{dl}$ & $25.4 \mathrm{mg} / \mathrm{dl}$ \\
25(OH)vitamin D (n.v. 30-100) & $16 \mathrm{ng} / \mathrm{ml}$ & $16 \mathrm{ng} / \mathrm{ml}$ & $40.7 \mathrm{ng} / \mathrm{ml}$ & - \\
U Ca (n.v. <4 mg/Kg) & - & $658 \mathrm{mg} / 24 \mathrm{~h}$ & $315 \mathrm{mg} / 24 \mathrm{~h}$ & $325 \mathrm{mg} / 24 \mathrm{~h}$ \\
Cr Clearance (n.v. 70-120 ml/min) & - & $67 \mathrm{ml} / \mathrm{min}$ & $55 \mathrm{ml} / \mathrm{min}$ & $61 \mathrm{ml} / \mathrm{min}$ \\
Ca/Cr ratio & - & 0.041 & 0.031 & 0.030 \\
\hline
\end{tabular}




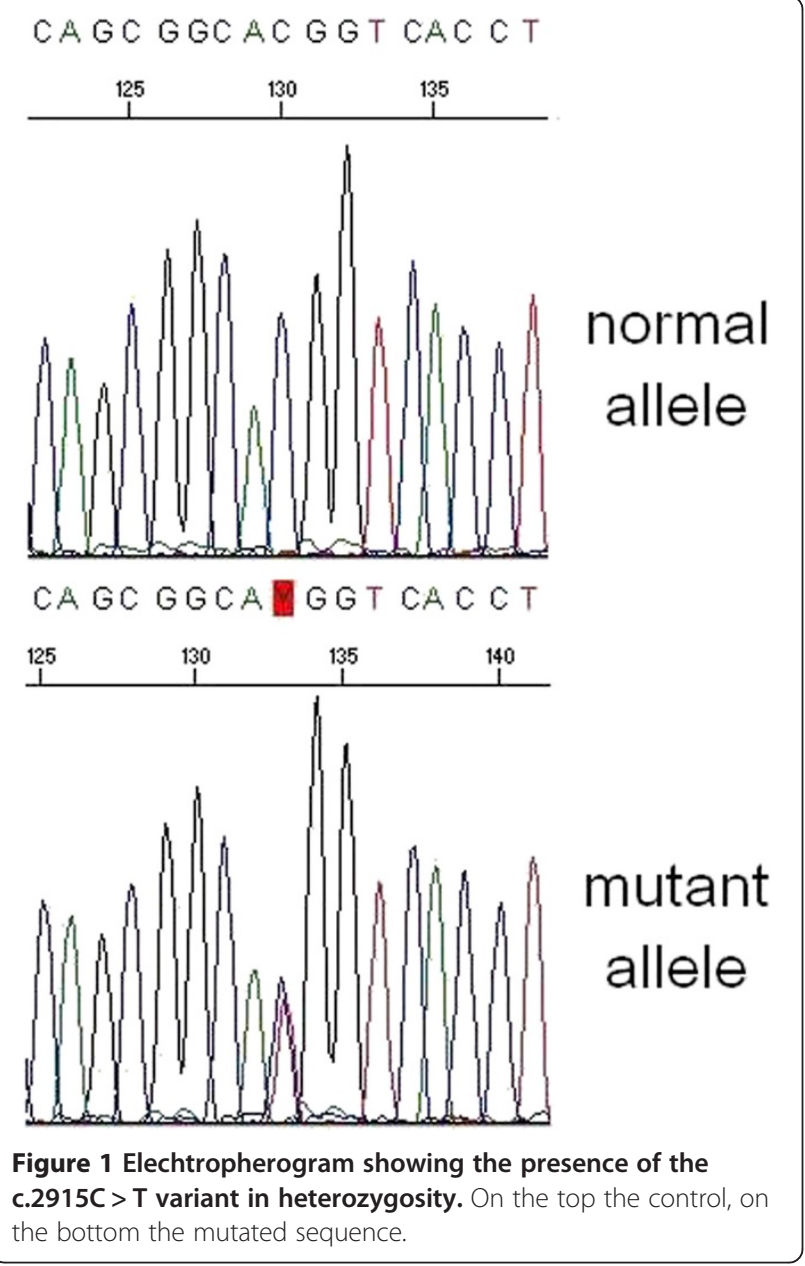

We also tested the mutation by either qualitative assay in order to investigate the protein conformation effect or by quantitative assay to verify in addition the alteration of protein function. In our functional assays on WT and mutant CaSR proteins, we showed that, with respect the WT, the $972 \mathrm{M}$ variant is slightly underexpressed as far as the $160 \mathrm{kDa}$ glycosylated form (Figure 3). The signaling activity of the $972 \mathrm{M}$ mutant receptor, compared to the WT, resulted strongly impaired even at higher $\mathrm{Ca}^{++}$ concentration $(10 \mathrm{mM})$, showing a pattern similar to the inactivating mutant control (Figure 4).

\section{Methods}

Calcium, phosphorous and creatinine were measured by automated laboratory methods. The urinary calcium and creatinine measurements were carried out on spot and on $24 \mathrm{~h}$ collection. PTH (Liaison 1-84 PTH, reference values $5-40 \mathrm{pg} / \mathrm{ml}$ ) and serum $25-\mathrm{OH}$-cholecalciferol were determined by chemiluminescence immunoassay (Diasorin-Liaison XL). Neck tomoscintigraphy was performed by injection of 99Tc-sesta MIBI.

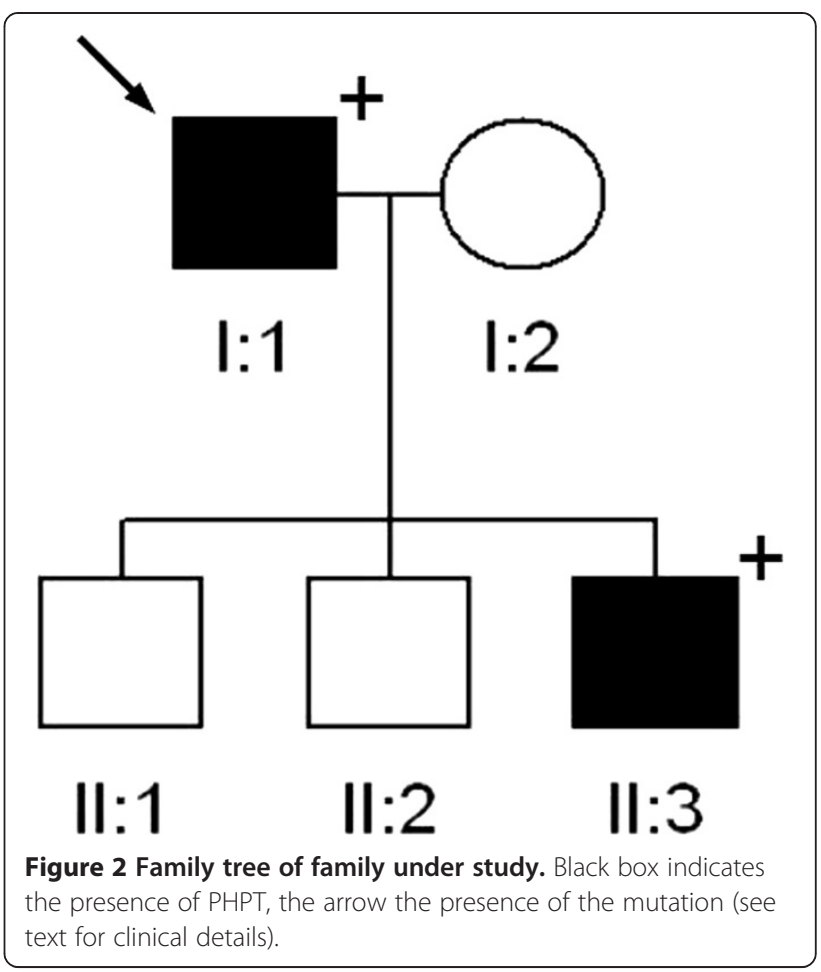

\section{Molecular analysis of CaSR gene}

DNA was extracted from peripheral blood leukocytes using standard protocol. Signed informed consent was obtained from all the subjects and the protocol was approved by local ethical committee of IRCCS "Casa Sollievo della Sofferenza" Hospital (San Giovanni Rotondo). Genetic screening of CaSR gene was performed by PCR amplification and direct sequencing of all the 7 exons (12 amplicons) including exon-intron boundaries as previously reported [18].

\section{cDNA expression vectors and mutagenesis}

The $972 \mathrm{M}$ variant was introduced in a Myc tagged human Wild Type (WT) CaSR cDNA expressing pCDNA3.1 vector: briefly, mutagenesis reaction was carried out with the

Table 2 Laboratory results (comparison among father and his affected son at genetic evaluation time)

\begin{tabular}{lcc}
\hline & Patient I:1 & $\begin{array}{c}\text { Patient's affected } \\
\text { son II:3 }\end{array}$ \\
\hline Age at diagnosis & 70 years old & 41 years old \\
s-Ca total (n.v. 8.8-10.6) & $12.96 \mathrm{mg} / \mathrm{dl}$ & $10.3 \mathrm{mg} / \mathrm{dl}$ \\
S-Ca++ (n.v. 1.12-1.31) & $1.62 \mathrm{mmol} / \mathrm{l}$ & $1.30 \mathrm{mmol} / \mathrm{l}$ \\
s-PO4 (n.v. 2.7-4.5) & $2.2 \mathrm{mg} / \mathrm{dl}$ & $3.3 \mathrm{mg} / \mathrm{dl}$ \\
s-PTH (n.v. 5-40) & $19.4 \mathrm{pg} / \mathrm{ml}$ & $23.5 \mathrm{pg} / \mathrm{ml}$ \\
25(OH)vitamin D (n.v. 30-100) & $40.7 \mathrm{ng} / \mathrm{ml}$ & $12.3 \mathrm{ng} / \mathrm{ml}$ \\
U Ca (v.n. <4 mg/kg) & $315 \mathrm{mg} / 24 \mathrm{~h}$ & $195 \mathrm{mg} / 24 \mathrm{~h}$ \\
Cr Clearance (n.v. 70-120 ml/min) & $55 \mathrm{ml} / \mathrm{min}$ & $107 \mathrm{ml} / \mathrm{min}$ \\
Ca/Cr ratio & 0.031 & 0.012 \\
\hline
\end{tabular}




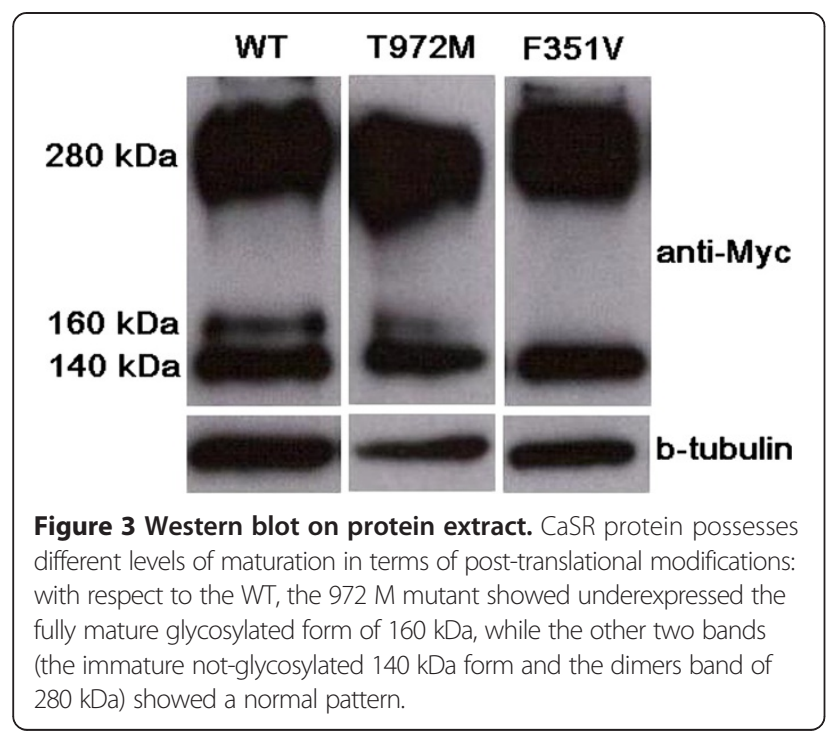

following primers (p.T972M, For: 5' -catctttggcagcggca Tggtcaccttctcactga- 3' and Rev: 5' -tcagtgagaaggtgacc Atgccgctgccaaagatg- 3, mutated base is in capital). One microlitre of Dpn1 (New England Biolabs) digested the parental DNA while $3 \mathrm{ul}$ of reaction was used to transform E.coli 5-alpha chemically competent cells (Lucigen). The mutated clone was identified by colony PCR and sequencing while midiprep performed with Plasmid Midi Kit (QIAGEN).

\section{Cell culture and transfection}

Human Embrionic Kidney (HEK293, ECACC) cells were cultured in DMEM/F12 (Sigma) supplemented with FBS $10 \%$ (Sigma) and penicillin/streptomycin 5\% (SIGMA) at $37^{\circ} \mathrm{C}$ with $\mathrm{CO}_{2} 5 \%$.

\section{Western blot on crude lysate protein extracts}

200 thousands HEK293 cells were seeded in 12 wells plates and transfected with Myc-tagged CaSR WT and mutant vectors (T972M and F351V, this latter as inactivating control) in triplicate. 48 hours after transfection, total cell proteins were extracted in RIPA buffer [150 $\mathrm{mMNaCl}, 50 \mathrm{mM}$ Tris- $\mathrm{HCl}, 1 \%$, Nonidet P- $40,0.1 \%$ sodium dodecyl sulfate (SDS), $0.5 \%$ sodium deoxycholate, $\mathrm{pH}$ 8.0] supplemented with one tablet $/ 10 \mathrm{~mL}$ of PhosStop and Complete EDTA, phosphatase and protease inhibitors (both from Roche). 50 ug of proteins were loaded onto a $8 \%$ SDS polyacrylamide gel, electrotransferred to PVDF membrane (Millipore, Billerica, MA), blotted overnight at $4^{\circ} \mathrm{C}$ with rabbit anti Myc monoclonal antibody (Cell Signaling Technology, 1:800 in blocking solution) and for $1 \mathrm{~h}$ at room temperature with the horseradish peroxidase-conjugated goat anti-rabbit IgG antibody (Santa Cruz Biotechnology) as secondary antibody. Membrane was stripped with Re-Blot Solution (Millipore) and re-blotted with b-tubulin rabbit monoclonal antibody (Cell Signaling Technology, 1:1000 in blocking solution) as loading control.

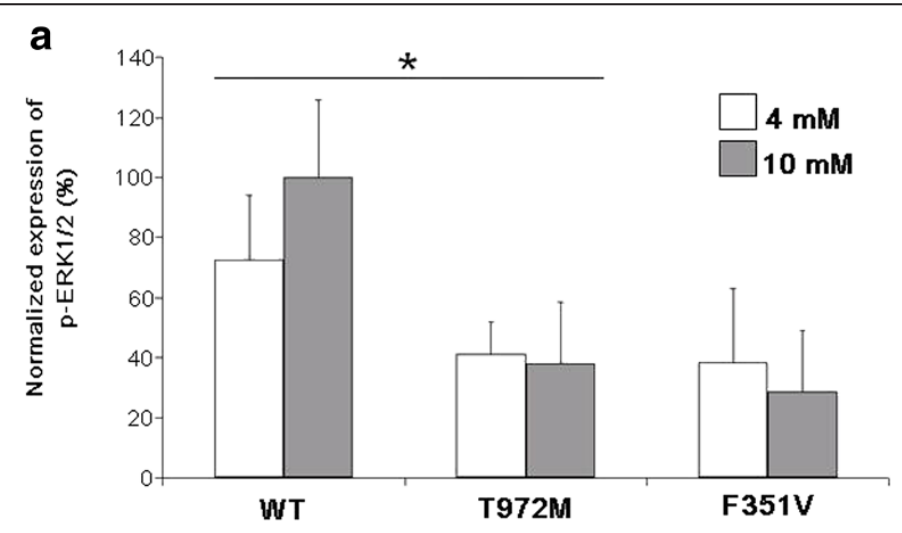

b

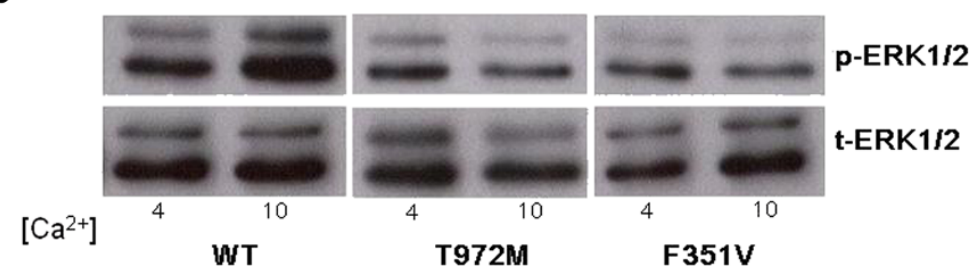

Figure 4 CaSR signaling activity measured as the ratio between the level of phosphorylated and total p42/44 proteins. a: compared with the WT for both the $\mathrm{Ca}^{2+}$ concentrations, the $972 \mathrm{M}$ variant induced a lower level of phosphorylation, similarly to the activity mediated by the inactivating control (F351V). Values were normalized with respect to the WT at $10 \mathrm{mM}$. Data are reported as mean \pm SEM of three replicate experiments. ${ }^{*}=p<0.05$ compared with the $W T ; \mathbf{b}$ : a representative western blot was shown. 


\section{MAP Kinase assay}

750 thousand HEK293 cells were seeded in 6 wells plates and transfected in 6 replicates with WT or mutant vectors using Lipofectamine 2000 (Invitrogen). After $24 \mathrm{~h}$ cells were starved with DMEM/F12 without $\mathrm{Mg}^{++}$and with minimal $\mathrm{Ca}^{++}$concentration (0,5 mM final). $48 \mathrm{~h}$ after the transfection, cells were stimulated in triplicates for each vector with 4 or $10 \mathrm{mM} \mathrm{CaCl}$ for $5 \mathrm{~min}$. Whole-cell extracts were made with RIPA buffer supplemented with cocktail inhibitors as above described. 80 ug of proteins were loaded onto a $12 \%$ SDS-PAGE and analyzed for expression of phosphorylated and total ERK1/2 proteins by immunoblotting with rabbit Phospho p42/44 and rabbit Total p42/44 antibodies, respectively (Cell Signaling Technology) according to the manufacturer's protocol. Secondary antibody was as above described. The Image J-National Institutes of Health image processing program (http://rsb. info.nih.gov/ij/) was used for signal densitometry by determining the ratios of the phosphorylated to nonphosphorylated ERK1/2 signals at various extracellular calcium concentrations and then normalized to the ratio of phosphorylated to unphosphorylated ERK1/2 at $10 \mathrm{mM}\left[\mathrm{Ca}^{++}\right]$.

\section{Statistical analysis}

Results are expressed as mean and standard deviation derived from triplicates experiments. A p-value $<0.05$ was considered for statistical significance.

\section{Discussion}

Familial hyperparathyroidism is a wide spectrum of disorders including multiple endocrine neoplasia types 1 (MEN 1) and 2A, hyperparathyroidism-jaw-tumor syndrome (HPT-JT), familial hypocalciuric-hypercalcemia $(\mathrm{FHH})$ and familial isolated hyperparathyroidism (FIHP) $[16,17]$. We report the case of FHH (an adult men and his son) affected by a novel mutation in CaSR gene. The screening of the whole coding sequence of the CaSR gene led to the identification of a novel variant of the exon 7 , namely c.2915C > T, p.T972M (Figure 1) in heterozygosity. This variant was absent on the public CaSR database (http://www.casrdb.mcgill.ca/; last access: may 2014) nor on either the Mutation Discovery and 1000 Genomes databases (http://www.mutationdiscovery.com/md/MD. com/home_page.jsp; www.1000genomes.org/; last access: may 2014), thus ruling out the possibility that it was a rare polymorphism. The segregation analysis enlarged to the available first degree relatives (Figure 2) allowed the identification of one carrier (II:3), the affected patient's son, a 41-year-old men, who is currently asymptomatic and shows serum ionized calcium reaching upper value $(1.30 \mathrm{mmol} / \mathrm{L})$ of normal range $(1.12-1.31 \mathrm{mmol} / \mathrm{L})$, normal calciuria and PTH. This point mutation, inherited in heterozygosity and implicated in inactivating CaSR, leads to a loss of function of the receptor, with evidence, in the father, of hypercalcemia and unsuppressed PTH levels. In classic form of this disorder, there is normal or hypocalciuria $(\mathrm{Ca} / \mathrm{Cr}$ ratio $<0.01)$, as expected when there is a point mutation confined in extracellular and transmembrane domains of CaSR.

In our subject, instead, there is evidence of hypercalciuria, in line with Carling et al. study [19], that identified a family with a heterozygous inactivating mutation of the cytoplasmic domain of the CaSR, not far from that of the patients in our study, associated with hypercalcemia, hypercalciuria and unsuppressed PTH. In that family, parathyroid surgery was performed in seventeen kindreds and in some cases, hyperplasia and nodule formations interpreted as single adenoma were found. By contrast to these previous reports, no image related to parathyroids hyperplasia or adenoma was detected in both subjects. The presence of polycystic kidney and jaw-cementoma in childhood can contribute to ambiguity in distinguishing an atypical form of $\mathrm{FHH}$ from HPT-JT. The absence of parathyroid adenoma, no visible jaw-cementoma in the recent orthopantomography and CaSR gene mutation, not associated to HPT, likely exclude HPT-Jaw tumor syndrome. In our functional assays on WT and mutant CaSR proteins, the western blot, performed on protein crude lysates extracted from cells transfected with WT and mutants CaSR vectors, showed that, with respect to the WT, the $972 \mathrm{M}$ variant is slightly underexpressed as far as the $160 \mathrm{kDa}$ glycosylated form. Instead either the immature not-glycosilated $140 \mathrm{kDa}$ and the higher $280 \mathrm{kDa}$ band suggestive of the CaSR dimers, appeared similar to the WT (Figure 3). The N-glycosylation at eight sites (N-90, N-130, N-261, N-287, N-446, N-468, N-488, and N-541) of the human CaSR have been proved to be important for a proper cell surface expression $[20,21]$. The process takes place in the ER and the fully glycosylation ends in the Golgi. So far several CaSR mutations not specifically affecting the 8-N have been functional tested and in many cases they showed a decrease of the expression of the $160 \mathrm{kDA}$ band [22,23]. In these cases an impairment of the trafficking from the ER towards the Golgi is hypothesized, rather than a defect in the $\mathrm{N}$-glycosylation process per se, even if in both the cases the final effect is a decrease of the cell surface expression [24]. With regard the signaling activity of the mutant receptor, compared to the WT, the $972 \mathrm{M}$ mutant resulted strongly impaired even at higher $\mathrm{Ca}^{++}$concentration $(10 \mathrm{mM})$, with a lower phosphorilation rate of ERK $1 / 2$, showing a pattern similar to the inactivating mutant control (Figure 4).

\section{Conclusions}

This is a case of a novel inactivating point mutation of CaSR gene that determines an atypical clinical presentation of $\mathrm{FHH}$ with hypercalciuria. In the functional assays we showed that the $972 \mathrm{M}$ variant influenced the maturation of the protein, in terms of the post-translational 
glycosylation. The impairment of the receptor activity is in keeping with the specific localization of the 972 residue in the C-terminal tail, which is assigned to the intracellular signaling. It seems that this CaSR mutation influences the intracellular signaling in parathyroid cells but not in kidney, suggesting the existence in these two sites of distinct intracellular pathways. The reported case may likely contribute to enlarge the expanding clinical spectrum of CaSR inactivating mutations.

\section{Consent}

Written informed consent was obtained from the patient for publication of this Case Report and any accompanying images. A copy of the written consent is available for review by the Editor of this journal.

\section{Abbreviations \\ HPT: Familial hyperparathyroidism; FHH: Familial benign hypocalciuric hypercalcemia; CaSR: Calcium-sensing receptor; MEN: Multiple endocrine neoplasia; APCA: Anti-parietal-cells-antibody; DXA: Bone density scan; HPT-JT: Hyperparathyroidism-jaw-tumor syndrome; FIHP: Familial isolated hyperparathyroidism; WT: Wild type.}

\section{Competing interests}

The authors declare that they have no competing interests.

\section{Authors' contributions}

EM made substantial contributions to conception and design and drafted the manuscript. FB, LC and VG made their contribution in genetics and functional assay. OL, MRC and AC participated in the design of the study and acquisition of data. MC and AS conceived of the study, and participated in its design and coordination and helped to draft the manuscript and to revise it critically for important intellectual content. All authors read and approved the final manuscript.

\section{Acknowledgments}

We gratefully acknowledge Geoffrey N Hendy (Calcium Research Laboratory, Royal Victoria Hospital and McGill University Health Centre, Montreal, QC, Canada) for the generous gift of the Myc tagged CaSR cDNA expressing vector.

\section{Author details}

${ }^{1}$ Unit of Endocrinology and Metabolic Diseases, Department of Medical and Surgical Sciences, University of Foggia, Italy, Viale Pinto, 1, 71122 Foggia, Italy. ${ }^{2}$ Medical Genetics Service IRCCS "Casa Sollievo della Sofferenza" Hospital viale Padre Pio, 71013 San Giovanni Rotondo (FG), Italy. ${ }^{3}$ Unit of Endocrinology and Metabolic Diseases IRCCS "Casa Sollievo della Sofferenza" Hospital viale Padre Pio, 71013 San Giovanni Rotondo (FG), Italy.

Received: 24 June 2014 Accepted: 29 September 2014

Published: 7 October 2014

\section{References}

1. Brown EM, MacLeod RJ: Extracellular calcium sensing and extracellular calcium signaling. Physiol Rev 2001, 81:239-297.

2. Pidasheva S, Grant M, Canaff L, Ercan O, Kumar U, Hendy GN: Calcium sensing receptor dimerizes in the endoplasmic reticulum: biochemical and biophysical characterization of CASR mutants retained intracellularly. Hum Molecul Genet 2006, 15:2200-2209.

3. Jiang JF, Zhang Z, Kifor O, Lane CR, Quinn SJ, Bai M: Protein kinase C (PKC) phosphorylation of the Ca-sensing receptor (CaR) modulates functional interaction of G proteins with the CaR cytoplasmic tail. J BiolChem 2002, 52:50543-50549.

4. Pi M, Spurney RF, Tu Q, Hinsos T, Quarles LD: Calcium-sensing receptor activation of Rho involves filamin and Rho-guanine nucleotide exchange factor. Endocrinol 2002, 143:3830-3838.

5. Gamba G, Friedman PAF: Thick ascending limb: the $\mathrm{Na}+\mathrm{K}+: 2 \mathrm{Cl}$ cotransporter, NKCC2, and the calcium-sensing receptor, CaSR. Eur J Physiol 2009, 458:61-76.
6. Ward DT: Calcium receptor-mediated intracellular signalling. Cell Calcium 2004, 35:217-228.

7. Vezzoli G, Soldati L, Gambaro G: Roles of calcium-sensing receptor (CaSR) in renal mineral ion transport. Curr Pharm Biotechnol 2009, 10:302-310.

8. Riccardi D, Hall AE, Chattopadhyay N, Hu JZ, Brown EM, Hebert SC: Localization of the extracellular Ca21/polyvalent cation-sensing protein in rat kidney. Am J Physiol Renal Physiol 1998, 43:F611-F622.

9. Riccardi D, Hall AE, Chattopadhyay N, Hu JZ, Brown EM, Hebert SC: Localization of the extracellular $\mathrm{Ca} 2+$ /polyvalent cation-sensing protein in rat kidney. Am J Physiol Renal Physiol 1998, 274:F611-F622.

10. Blankenship KA, Williams JJ, Lawrence MS, McLeish KR, Dean WL, Arthur JM: The calcium-sensing receptor regulates calcium absorption in MDCK cells by inhibition of PMCA. Am J Physiol 2001, 280:815-822.

11. Bilezikian JP, Marcus R, Levine MA: The parathyroids Heath DA. Familial hypocalciuric hypercalcemia. New York: Raven Press, Ltd; 1994:699-710.

12. Favus MJ, Marx SJ: Familial hypocalciuric hypercalcemia. Primer on the metabolic bone disease and disorders of mineral metabolism. Philadelphia: Lippincott-Raven; 1996.

13. Marx SJ, Attie MF, Levine MA, Spiegel AM, Downs RW Jr, Lasker RD: The hypocalciuric or benign variant of familial hypercalcemia: clinical and biochemical features in fifteen kindreds. Medicine 1981, 60:397-412.

14. Law V Jr, Carney J, Heath H III: Parathyroid glands in familial benign hypercalcemia (familial hypocalciuric hypercalcemia). Am J Med 1984, 76:1021-1026

15. Teh BT, Farnebo F, Twigg S, Höög A, Kytölä S, Korpi-Hyövälti E, Wong FK, Nordenström J, Grimelius L, Sandelin K, Robinson B, Farnebo LO, Larsson C Familial isolated hyperparathyroidism maps to the hyperparathyroidism-jaw tumor locus in 1q21-q32 in a subset of families. J ClinEndocrino/Metab 1998, 83:2114-2120.

16. Heath H III, Hobbs MR, Favus MJ: Familial hyperparathyroid syndromes. Primer on the metabolic bone disease and disorders of mineral metabolism. Philadelphia: Lippincott-Raven; 1996:187-189.

17. Szabó J, Heath B, Hill VM, Jackson CE, Zarbo RJ, Mallette LE, Chew SL, Besser GM, Thakker RV, Huff V: Hereditary hyperparathyroidism-jaw tumor syndrome: the endocrine tumor gene HRPT2 maps to chromosome 1q21-q31. Am J Hum Genet 1995, 56:944-950.

18. Guarnieri V, Valentina D'Elia A, Baorda F, Pazienza V, Benegiamo G, Stanziale P, Copetti M, Battista C, Grimaldi F, Damante G, Pellegrini F, D'Agruma L, Zelante $L$, Carella M, Scillitani A: CASR gene activatingmutations in two families with autosomaldominanthypocalcemia. Mol Genet Metab 2012, 3:548-552.

19. Carling T, Szabo E, Bai M, Ridefelt P, Westin G, Gustavsson P, Trivedi S, Hellman P, Brown E, Dahl N, Rastad J: Familial hypercalcemia and hypercalciuria caused by a novel mutation in the cytoplasmic tail of the calcium receptor. J Clin Endocrinol Metab 2000, 85(5):2042-2047.

20. Fan G, Goldsmith PK, Collins R, Dunn CK, Krapcho KJ, Rogers KV, Spiegel AM: $\mathrm{N}$-linked glycosylation of the $\mathrm{Ca} 2+$ receptor is essential for its expression at the cell surface. Endocrinology 1997, 138:1916-1922.

21. Ray K, Clapp P, Goldsmith PK, Spiegel AM: Identification of the sites of $\mathrm{N}$-linked glycosylation on the human calcium receptor and assessment of their role in cell surface expression and signal transduction. J Biol Chem 1998, 273:34558-34567.

22. Pidasheva S, Grant M, Canaff L, Ercan O, Kumar U, Hendy GN: Calciumsensing receptor dimerizes in the endoplasmic reticulum: biochemical and biophysical characterization of CASR mutants retained intracellularly. Hum Mol Genet 2006, 14:2200-2209.

23. Guarnieri V, Canaff $L$, Yun FH, Scillitani A, Battista C, Muscarella LA, Wong BY, Notarangelo A, D'Agruma L, Sacco M, Cole DE, Hendy GN: Calcium-sensing receptor (CaSR) mutations in hypercalcemic states: studies from a single endocrine clinic over three years. J Clin Endocrinol Metab 2010, 4:1819-1829.

24. Pidasheva S, Canaff L, Simonds WF, Marx SJ, Hendy GN: Impaired cotranslational processing of the calcium-sensing receptor due to signal peptide missense mutations in familial hypocalciuric hypercalcemia. Hum Mol Genet 2005, 12:1679-1690.

doi:10.1186/1472-6823-14-81

Cite this article as: Mastromatteo et al:: A novel mutation in calciumsensing receptor gene associated to hypercalcemia and hypercalciuria. BMC Endocrine Disorders 2014 14:81. 